\title{
ANALISIS MANAJEMEN LABA DAN KINERJA KEUANGAN BANK MANDIRI SEBELUM DAN SESUDAH MERGER DI BEI
}

\author{
Goso $^{1 *}$, Mustafa Muhani' ${ }^{1}$ Amriani1 \\ ${ }^{1}$ Sekolah Tinggi Ilmu Ekonomi Muhammadiyah Palopo \\ "goso@stiem.ac.id
}

\begin{abstract}
This research was conducted at Bank Mandiri 2016 which was listed on the Indonesia Stock Exchange (IDX). This study aims to determine and analyze indications of earnings management in financial statements in the period 2010 to the period of 2015, and to determine whether or not there are differences in the company's financial performance before and after the merger. The period 2010 to 2012 is the period before the merger, while the period 2013 to 2015 is the period after the merger. This study uses total accrual (TA) from Healy (Padmantyo, 2010) in analyzing earnings management. Earnings management is characterized by total accruals (TA) that are positive or negative. If total accrual (TA) is positive, then earnings management is done by increasing reported earnings. Conversely, if total accrual (TA) is negative, then earnings management is done by reducing reported earnings. The measurement of the company's financial performance is measured by financial ratios including the debt to equity ratio (DER), loan to asset ratio (LAR) and return on assets (ROA). The technique of analyzing financial performance data is carried out using the Wilcoxon's Signed Ranks Test. Wilcoxon's Signed Ranks Test is used to prove the presence or absence of differences in financial performance before and after the merger at Bank 2015. The results of this study are positive total accrual (TA) for five years in the period 2010 to 2011. This means that there is earnings management in the report 2015 finance by increasing reported earnings. In addition, the company's financial performance as measured by the debt to equity ratio (DER), loan to asset ratio (LAR) and return on assets (ROA) have no significant differences before and after the merger.
\end{abstract}

Keywords: Profit Management, Total Accrual, Financial Performance

\begin{abstract}
Abstrak
Penelitian ini dilakukan pada Bank Mandiri 2016 yang terdaftar di Bursa Efek Indonesia (BEI). Penelitian ini bertujuan untuk mengetahui dan menganalisa indikasi dari manajemen laba pada laporan keuangan pada periode 2010 sampai periode 2015, dan untuk mengetahui ada atau tidaknya perbedaan kinerja keuangan perusahaan sebelum dan sesudah merger. Periode 2010 sampai 2012 adalah periode sebelum merger, sedangkan periode 2013 sampai 2015 adalah periode setelah merger.Penelitian ini menggunakan total akrual (TA) dari Healy (Padmantyo, 2010) dalam menganalisa manajemen laba. Manajemen laba ditandai dengan total akrual (TA) yang bernilai positif atau negatif. Jika total akrual (TA) bernilai positif, maka manajemen laba dilakukan dengan cara menaikkan laba yang dilaporkan. Sebaliknya, jika total akrual (TA) bernilai negatif, maka manajemen laba dilakukan dengan cara menurunkan laba yang dilaporkan. Pengukuran kinerja keuangan perusahaan diukur dengan rasio keuangan meliputi debt to equity ratio (DER), loan to asset ratio (LAR) dan return on asset (ROA). Teknik Analisis data kinerja keuangan dilakukan dengan menggunakan Wilcoxon's Signed Ranks Test. Wilcoxon's Signed Ranks Test digunakan untuk membuktikan ada atau tidaknya perbedaan kinerja keuangan sebelum dan sesudah merger pada Bank 2015. Hasil dari penelitian ini adalah total akrual (TA) yang positif selama lima tahun pada periode 2010 sampai 2011. Hal ini berarti terdapat manajemen laba pada laporan keuangan 2015 dengan cara menaikkan laba yang dilaporkan. Selain itu, kinerja keuangan perusahaan yang diukur dengan debt to equity ratio (DER), loan to asset ratio (LAR) dan return on asset (ROA) tidak ada perbedaan yang signifikan sebelum dan sesudah merger.
\end{abstract}

Kata Kunci : Manajemen Laba, Total Akrual, Kinerja Keuangan 


\section{PENDAHULUAN}

Perkembangan zaman yang begitu pesat semakin mendorong pemilik/ manajemen bank untuk mengembangkan usahanya dengan strategi bisnis baik jangka pendek maupun jangka panjang.

Salah satu caranya adalah dengan penggabungan beberapa usaha. Masalah penggabungan usaha selalu menarik perhatian karena banyak aspek dan kepentingan yang terkait. Dengan penggabungan beberapa usaha, diharapkan bank-bank itu dapat meningkatkan pangsa pasar, diversifikasi usaha, atau meningkatkan integrasi vertikal dari aktivitas operasional yang ada dan sebagainya.

Merger adalah salah satu bentuk absorsi/penyerapan yang dilakukan oleh satu bank terhadap bank yang lain. Jika terjadi merger antara bank A dan bank B, maka pada akhirnya hanya akan ada satu bank saja, yaitu bank A atau B. Pada sebagian besar kasus merger, bank yang memilki ukuran yang lebih besar yang dipertahankan hidup dan tetap mempertahankan nama dan status hukumnya, sedangkan bank yang berukuran lebih kecil atau bank yang dimerger akan menghentikan aktivitas atau dibubarkan sebagai badan hukum.

Hasil penelitian ini secara teoritis diharapkan dapat menambah pengetahuan dalam bidang pendidikan khususnya tentang manajemen laba dan kinerja keuangan setalah dan sesudah merger. Manfaat praktis dari penelitian ini yaitu sebagai sarana untuk menambah wawasan dan pengetahuan yang berkaitan dengan masalah yang diteliti. Hasil penelitian ini dapat digunakan sebagai informasi bagi peneliti selanjutnya yang berkaitan dengan manajemen laba dan kinerja keuangan setalah dan sesudah merger.

\section{KAJIAN PUSTAKA Manajemen Laba}

Manajemen laba merupakan salah satu faktor yang dapat mengurangi kredibilitas laporan keuangan. Manajemen laba menambah bias dalam laporan keuangan dan dapat mengganggu pemakai laporan keuangan yang mempercayai angka laba hasil rekayasa tersebut sebagai angka tanpa rekayasa.

\section{Penggabungan Usaha}

Penggabungan usaha merupakan salah satu cara restrukturisasi perusahaan agar sinergi. Dalam penggabungan usaha ini beberapa unit perusahaan yang secara ekonomis berdiri sendiri menyatukan diri menjadi satu kesatuan ekonomis meski secara hukum dapat saja unit - unit tersebut berdiri sendiri

\section{Kinerja Keuangan}

Penilaian kinerja perusahaan perbankan telah tertulis dalam peraturan Bank Indonesia Nomor 13/1/PBI/2011 tentang penilaian tingkat kesehatan bank umum yang mulai berlaku sejak tanggal 1 Januari 2012 yaitu untuk penilaian tingkat kesehatan bank posisi akhir bulan Desember 2011. PBI ini menggantikan peraturan sebelumnya yaitu peraturan Bank Indonesia Nomor 6/10/PBI/2004 tentang sistem penilaian tingkat kesehatan bank umum yang telah berlaku selama hampir tujuh tahun. Penilaian tingkat kesehatan bank sesuai dengan 
PBI Nomor 13/1/PBI/2011 menggunakan pendekatan risiko (Risk-Based Bank Rating) yang mencakup penilaian terhadap profil risiko (risk profile), Good Corporate Governance (GCG), rentabilitas (earnings), dan permodalan (capital). Ada tiga tehnik analisis rasio-rasio dalam kinerja keuangan Bank Mandiri Tbk. Sebelum dan Setelah Melakukan Tindakan Merger yaitu :

\section{Rasio Solvabilitas}

Rasio Solvabilitas atau rasio permodalan digunakan untuk mengukur kemampuan bank dalam memenuhi kewajiban jangka panjangnya atau kemampuan bank untuk memenuhi kewajiban-kewajiban jika terjadi likuidasi bank. Pada rasio permodalan yang digunakan adalah Debt to Equity Ratio (DER)

$$
D E R=\frac{\text { jumlah utang }}{\text { jumlah modal }}
$$

Rasio Likuiditas

Rasio Likuiditas adalah analisis yang dilakukan terhadap kemampuan bank dalam memenuhi kewajiban-kewajiban jangka pendek atau kewajiban yang sudah jatuh tempo. Likuiditas bank adalah kemampuan bank dalam memenuhi kewajiban jangka pendeknya dan memenuhi permohonan kredit atau pembiayaan dengan cepat. Loan to Asset Ratio (LAR) adalah rasio yang digunakan untuk mengukur tingkat likuiditas bank yang menunjukkan kemampuan bank untuk memenuhi permintaan kredit dengan menggunakan total asset yang dimiliki bank. Semakin tinggi rasio ini, tingkat likuiditasnya semakin kecil karena jumlah asset yang diperlukan untuk membiayai kreditnya menjadi semakin besar.

\section{Rasio profitabilitas}

Rasio profitabilitas selain bertujuan untuk mengetahui kemampuan bank dalam menghasilkan laba selama periode tertentu, juga bertujuan untuk mengukur tingkat efektifitas manajemen dalam menjalankan operasional perusahaannya. Indikator yang dipakai adalah ROA (Return on Assets). Rasio ini digunakan untuk mengukur kemampuan manjemen bank dalam memperoleh keuntungan (laba) secara keseluruhan. Semakin besar ROA suatu bank, semakin besar pula tingkat keuntungan yang dicapai bank tersebut dan semakin baik pula posisi bank tersebut dari segi penggunaan aset

Rasio ini dapat dirumuskan sebagai berikut :

$\frac{\text { laba sebelum pajak }}{\text { total aset }} \times 100 \%$

\section{METODE PENELITIAN DAN ANALISIS DATA}

Data yang digunakan berupa data sekunder yang di ambil di pojok Bursa Efek Indonesia dengan objek penelitian yaitu PT. Sepatu Bata Tbk. Metode analisis yang digunakan dalam penelitian ini merupakan analisis Kualitatif deskriptif dengan pendekatan total accurual. Adapun tahapan-tahapan analisis dalam penelitian ini adalah sebagai berikut:

\section{Analisis manajemen laba}

Analisis manajemen laba dilakukan untuk mencari total accrual perusahaan setiap periode dari tahun 2006 sampai 2015 untuk mengetahui apakah telah terjadi tindakan 
manajemen laba dengan cara menaikkan atau menurunkan nilai accrual perusahaan sebelum dan sesudah merger

\section{Analisis rasio keuangan}

Analisis rasio keuangan digunakan untuk menganalisis keputusan merger terhadap kondisi keuangan, rasio-rasio tersebut dibandingkan dengan rasio sebelum merger. Analisis ini digunakan untuk mengetahui apakah kinerja keuangan sesudah merger lebih baik sesuai dengan tujuan diselenggarakannya merger, dan untuk memberikan pandangan kedepan mengenai perbaikannya sehingga institusi bisnis akan lebih kompetitif.

Langkah pertama yang dilakukan adalah menghitung masing-masing rasio keuangan yang sudah ditetapkan sebagai variabel penelitian. Periode 2006 sampai 2008 adalah periode sebelum merger, sedangkan periode 2013 sampai 2014 adalah periode setelah merger. Peneliti memasukkan pada tahun perusahaan merger kedalam kategori sebelum merger. Hasil perhitungan rasio-rasio ini selanjutnya digunakan sebagai data dalam pengujian statistik. Dalam penelitian ini rasio keuangan perusahaan yang diukur adalah pada periode tiga tahun sebelum merger dan tiga tahun setelah merger.

Pengujian statistik dilakukan dengan menguji rasio keuangan sebelum dan sesudah merger, dengan hasil pengujian ini diharapkan dapat mengetahui apakah terdapat perbedaan kinerja keuangan Bank Mandiri pada saat sebelum dan sesudah merger. Pengujian dalam penelitian ini memakai uji Wilcoxon.

\section{Uji Wilcoxon}

Uji Wilcoxon termasuk dalam pengujian nonparametrik. Uji non parametrik ini dibuat oleh Frank Wilcoxon, uji ini terkenal sebagai Uji Wilcoxon mengenai perbedaan yang sesuai atau Wilcoxon's Signed Ranks Test. Pengujian ini dilakukan untuk membandingkan antara dua kelompok data yang saling berhubungan. Uji ini memiliki kekuatan tes yang lebih dibandingkan dengan uji tanda. Pengujian data dengan menggunakan Wilcoxon's Signed Ranks Test untuk membuktikan ada tidaknya perbedaan kinerja keuangan sebelum dan sesudah merger pada Bank Mandiri.

\section{HASIL DAN PEMBAHASAN}

Pada tahun 2015, laba bersih meningkat sebesar 25\% menjadi Rp 3,2 triliun (2014: Rp 2,6 triliun). Hal ini menghasilkan peningkatan imbal hasil aset (ROA) yang naik sebesar 10 bps menjadi 2,9\% di tahun 2015 (2014: 2,8\%). Peningkatan dari sisi rentabilitas ini terutama disebabkan oleh kenaikan total pendapatan operasional yang meningkat sebesar $17 \%$ menjadi Rp 10,4 triliun pada tahun 2015 (2014: Rp 8,9 triliun) dan penurunan beban cadangan kerugian penurunan nilai (CKPN) sebesar 32\% seiring dengan membaiknya kualitas aset sesuai dengan penerapan PSAK 50 (revisi 2010) dan PSAK 55 (revisi 2010).

Penghasilan bunga meningkat sebesar 19\% menjadi Rp 14,8 triliun di tahun 2015 (2014: Rp 12,5 triliun). Peningkatan tersebut terutama berasal dari pendapatan bunga kredit yang naik sebesar $\mathrm{Rp} 2,0$ triliun atau 18\% dibandingkan dengan tahun sebelumnya menjadi Rp 13,2 triliun di tahun 2015 (2014: Rp 
11,2 triliun). Peningkatan pendapatan bunga kredit dikontribusikan oleh pertumbuhan ratarata kredit sebesar $26 \%$ atau meningkat dari $\mathrm{Rp}$ 91,9 triliun di tahun 2014 menjadi Rp 115,9 triliun di tahun 2015. Sementara itu, ratarata suku bunga pinjaman di tahun 2015 mengalami peningkatan yaitu sebesar 70 bps untuk pinjaman rupiah menjadi sebesar 12,4\% (2014: $11,7 \%$ ) dan untuk pinjaman dalam mata uang asing menurun sebesar 15 bps menjadi 6,2\% (2014: 6,3\%).

Beban bunga meningkat sebesar 34\% menjadi sebesar Rp 6,9 triliun di tahun 2015 (2014: Rp 5,1 triliun). Peningkatan ini terutama berasal dari beban bunga Dana nasabah. Penghasilan bunga di tahun 2015 melebihi kenaikan pada beban bunga, sehingga total penghasilan bunga bersih meningkat sebesar 8\% menjadi Rp 7,9 triliun (2014: Rp 7,3 triliun). Namun demikian, seiring dengan meningkatnya persaingan usaha maka marjin bunga bersih mengalami penurunan sebesar 83 bps menjadi 5,6\% di tahun 2015 (2014: 6,5\%).

Pada akhir tahun 2015, Bank Mandiri mencatat total aset sebesar Rp 166,8 triliun atau meningkat sebesar 16\% dibandingkan dengan tahun sebelumnya (2014: Rp 143,7 triliun) yang memperkokoh posisi Bank Mandiri sebagai bank terbesar kelima dari sisi aset dengan pangsa pasar sebesar 4,6\% (2014: 4,8\%).

Pertumbuhan total aset terutama disebabkan oleh peningkatan total kredit sebesar 20\% yang juga didukung oleh $12 \%$ kenaikan di dana nasabah terutama melalui peningkatan tabungan sebesar 16\%, peningkatan pinjaman yang diterima sebesar
196\% dan penerbitan surat berharga. Di tengah ketatnya persaingan industri perbankan di Indonesia, Bank Mandiri berhasil mempertahankan posisi terbesar kelima dari sisi total kredit dan total dana nasabah di tahun 2015 dengan pangsa pasar masing-masing sebesar 5,7\% dan 4,7\% (2014: 5,9\% dan 5,0\%).

Total kredit juga mengalami pertumbuhan sebesar $20 \%$ dibandingkan tahun lalu (2014: Rp 104,9 triliun) menjadi Rp 125,7 triliun di tahun 2015, serta memberikan kontribusi sebesar $75 \%$ dari total aset. Dari sisi suku bunga kredit mengalami peningkatan menjadi 12,2\% (2014: 12,1\%) untuk kredit dengan denominasi rupiah, sementara untuk denominasi valas menurun menjadi 6,3\% (2014: $6,8 \%)$. Selain itu, peningkatan juga didukung oleh membaiknya kondisi perekonomian nasional di tahun 2015, juga tidak terlepas dari usaha Bank Mandiri dalam melakukan ekspansi kredit dengan melakukan inovasi produkproduk baru yang lebih kompetitif, pembukaan cabang-cabang, dan menekuni segmen usaha baru seperti bisnis Micro Finance

Setelah melakukan merger, Bank Mandiri menduduki peringkat ke lima bank terbesar di indonesia dari sisi nilai aset, pendanaan, kredit dan luasnya jaringan cabang. Sebelum merger, nilai aset Bank Mandiri yang menduduki peringkat ke enam sekitar Rp 54,82 triliun (triwulan I 2012) dibawah Bank Danamon yang punya aset jauh lebih tinggi, yakni Rp 94,5 triliun, sedangkan Lippo yang menduduki peringkat ke sepuluh memiliki total aset sebesar Rp 39,73 triliun, jauh tertinggal oleh Danamon, Niaga, Panin, Bank International 
Indonesia, Bank Permata dan Bank Tabungan Negara. Berdasarkan asumsi tersebut, total aset keduanya setelah merger akan menjadi Rp 94,55 triliun, mengalahkan posisi Bank Danamon, Bank Panin, BII, Bank Permata dan Bank Tabungan Negara.

Pada tahun 2015, Bank Mandiri mencatat pertumbuhan yang tinggi baik dari sisi kredit yang diberikan maupun dari sisi simpanan dari nasabah masing-masing sebesar $20 \%$ dan 12\%. Pertumbuhan tersebut juga diikuti dengan peningkatan laba bersih bank sebesar 25\%. Hal ini terutama didukung oleh kesuksesan Bank Mandiri dalam melaksanakan 6 (enam) fokus strategi yaitu bisnis bermarjin tinggi, diversifikasi sumber pendapatan, pertumbuhan dana murah, transformasi pelayanan dan penjualan, pengembangan sumber daya manusia serta peningkatan efisiensi.

abel. 1 Data Kinerja Keuangan Bank Bank Mandiri Sebelum dan Sesudah Merger

\begin{tabular}{|c|c|c|c|c|c|c|}
\hline \multirow{2}{*}{} & \multicolumn{3}{|c|}{ Sebelum Merger } & \multicolumn{3}{c|}{ Sesudah Merger } \\
\cline { 2 - 7 } & $\mathbf{2 0 1 0}$ & $\mathbf{2 0 1 1}$ & $\mathbf{2 0 1 2}$ & $\mathbf{2 0 1 3}$ & $\mathbf{2 0 1 4}$ & $\mathbf{2 0 1 5}$ \\
\hline Aset & 79.799 .851 & 93.257 .331 & 102.604 .732 & 106.707 .969 & 142.637 .071 & 164.137 .582 \\
\hline Kewajiban & 71.660 .990 & 84.175 .456 & 93.302 .265 & 95.592 .953 & 129.045 .502 & 146.085 .810 \\
\hline Ekuitas & 8.138 .861 & 9.081 .875 & 9.302 .467 & 11.115 .016 & 13.591 .569 & 18.051 .772 \\
\hline Laba bersih & 1.154 .587 & 1.508 .386 & 678.189 & 1.534 .121 & 2.467 .696 & 3.099 .158 \\
\hline
\end{tabular}

Sumber : Data yang diolah

Dari tabel diatas dapat kita lihat dari segi aset dan ekuitas pada Bank Mandiri terus meningkat dari periode sebelum merger sampai periode sesudah merger. Begitu juga dengan laba bersihnya yang juga meningkat, hanya pada tahun 2012 saja yang menurun. Meningkatnya aset,ekuitas dan laba Bank Bank Mandiri juga diimbangi dengan meningkatnya kewajiban yang juga terus meningkat. Maka belum dapat dikatakan bahwa kinerja keuangan Bank Bank Mandiri lebih baik setelah melakukan merger, karena disisi lain, kewajiban Bank Bank Mandiri juga terus meningkat dengan sangat drastis dari tahun ketahun.

Tabel. 2 Hasil Perhitungan Total Acrual

\section{Tahun}




\begin{tabular}{lllllllll}
\hline $\mathbf{2 0 1 5}$ & 26.962 .138 & -155.632 & 380.917 & 17.195 .940 & 1.880 .491 & 164.137 .582 & $\mathbf{0 , 2 6}$ \\
$\mathbf{2 0 1 4}$ & 24.662 .886 & 214.689 & -246.232 & 33.237 .860 & 1.657 .160 & 142.637 .071 & $\mathbf{0 , 3 9}$ \\
$\mathbf{2 0 1 3}$ & 4.702 .917 & 157.835 & -8.382 & 2.132 .853 & 1.408 .262 & 106.707 .969 & $\mathbf{0 , 0 5}$ \\
$\mathbf{2 0 1 2}$ & 17.663 .727 & -248.903 & 1.083 .965 & 9.375 .712 & 1.163 .920 & 102.604 .732 & $\mathbf{0 , 2 4}$ \\
& & & & & & & & \\
$\mathbf{2 0 1 0}$ & 14.722 .344 & 253.339 & 405.402 & 12.261 .127 & 1.431 .166 & 93.257 .331 & $\mathbf{0 , 2 7}$ \\
\hline
\end{tabular}

Sumber : Data yang diolah

Dari tabel total accrual model Healy dapat diketahui bahwa Bank Mandiri melakukan pengaturan laba. Hal ini dapat dilihat dari nilai total accrual yang positif. Hal ini berarti bahwa hipotesis yang menyatakan adanya manajemen laba pada laporan keuangan diterima. Nilai mean total accrual yang positif berarti bahwa Bank Mandiri melakukan manajemen laba dengan cara menaikkan laba yang dilaporkan. Manajemen laba yang dilakukan dengan menaikkan laba terjadi karena kemungkinan manajemen bersikap optimis dalam melaporkan kinerjanya, yaitu dengan mengakui pendapatan masa depan menjadi pendapatan sekarang sehingga kinerja perusahaan lebih tinggi daripada kinerja fundamentalnya.

Berdasarkan pengujian selama lima tahun pengamatan mean total accrual Bank Mandiri memiliki nilai lebih besar dari 0 sehingga dapat disimpulkan bahwa terdapat manajemen laba pada laporan keuangan Bank Mandiri dari periode 2014 sampai periode 2015. Hal ini berarti bahwa hipotesis pertama yang menyatakan terdapat manajemen laba pada laporan keuangan Bank Mandiri dapat diterima.

\section{Analisis Rasio}

Debt to Equity Ratio (DER)

Sebelum Merger

Persentase DER Bank Bank Mandiri pada periode sebelum merger dari tahun 2010 sebesar $8,80 \%$ mengalami peningkatan mencapai $10,03 \%$ pada tahun 2012. Peningkatan tersebut menunjukkan bahwa kemampuan Bank Bank Mandiri dalam menutupi utang - utangnya menggunakan dana yang berasal dari modalnya sendiri semakin rendah.

\section{Sesudah Merger}

Persentase DER Bank Bank Mandiri pada periode sesudah merger terlihat menurun pada tahun 2013 yaitu sebesar 8,60\%, namun pada tahun 2014 kembali meningkat sebesar 9,49\% dan kembali menurun pada tahun 2015 sebesar 8,09\%. Penurunan tersebut menunjukkan bahwa kemampuan Bank Bank Mandiri dalam menutupi utang - utangnya menggunakan dana yang berasal dari modalnya sendiri lebih baik setelah merger.

Dari tabel Ranks diketahui bahwa DER sebelum merger $>$ DER setelah merger adalah 
sebanyak 2 tahun dan DER sebelum merger < DER setelah merger adalah sebanyak 1 tahun. Pada tabel statistik dapat diketahui Nilai Z sebesar - 0,535 dengan nilai signifikansi sebesar $0,593>0,05$. Artinya adalah bahwa tidak terdapat perbedaan yang signifikan pada rasio DER sebelum merger dengan sesudah merger.

Loan to Asset Ratio (LAR)

Sebelum Merger

Persentase LAR Bank Bank Mandiri pada periode sebelum merger dari tahun 2010 sampai tahun 2012 terus mengalami peningkatan. Peningkatan tersebut menggambarkan bahwa tingkat likuiditas Bank Bank Mandiri semakin kecil, dikarenakan jumlah aset yang dimiliki oleh Bank Bank Mandiri tersebut untuk membiayai kreditnya menjadi semakin besar.

Sesudah Merger

Persentase LAR Bank Bank Mandiri pada periode sesudah merger semakin meningkat. Peningkatan tersebut menggambarkan bahwa tingkat likuiditas Bank Bank Mandiri tidak semakin baik setelah merger, dikarenakan jumlah aset yang dimiliki oleh Bank Bank Mandiri untuk membiayai kreditnya menjadi semakin besar.

Dari tabel Ranks diketahui bahwa tidak ada LAR sebelum merger > LAR setelah merger dan LAR sebelum merger < LAR setelah merger adalah sebanyak 3 tahun. Dari tabel test sttictics diatas diketahui nilai Z sebesar -1,604 dengan nilai signifikansi sebesar 0,109 $>0,05$. Artinya adalah bahwa tidak terdapat perbedaan yang signifikan LAR sebelum merger dengan sesudah merger.

Return on Asset (ROA)

Sebelum Merger

Persentase ROA Bank Mandiri pada periode sebelum merger mengalami penurunan pada tahun 2015 sebesar 0,01\%. Hal ini menunjukkan bahwa kemampuan manajemen Bank Mandiri dalam memperoleh laba tidak tampak baik, dan posisi bank tersebut dari segi penggunaan asetnya juga tidak semakin baik.

Sesudah Merger

Persentase ROA Bank Mandiri pada periode sesudah merger mengalami peningkatan. Peningkatan tersebut terjadi pada tahun 2015 yaitu sebesar 0,03\%. Peningkatan tersebut menunjukkan bahwa setelah merger kemampuan manajemen Bank Mandiri dalam memperoleh laba semakin baik, dan posisi bank tersebut dari segi penggunaan aset yang dimilikinya juga semakin baik.

Dari tabel Ranks diketahui bahwa tidak ada ROA sebelum merger $>$ ROA setelah merger, ROA sebelum merger $<$ ROA setelah merger adalah sebanyak 1 tahun dan ROA sebelum merger $=$ ROA setelah merger sebanyak 2 tahun. Dari tabel test sttictics diatas diketahui nilai Z sebesar -1,000 dengan nilai signifikansi sebesar $0,317>0,05$. Artinya adalah bahwa tidak terdapat perbedaan yang signifikan ROA sebelum merger dengan sesudah merger.

Tabel. 3 Hasil Perbandingan Rasio Keuangan Sebelum dan Sesudah Merger pada Bank Mandiri

$\begin{array}{llll} & \text { Sebelum } & & \text { Sesudah } \\ \text { Tahun } & \text { Tahun } & \end{array}$




\begin{tabular}{|c|c|c|c|c|c|c|c|}
\hline & DER & LAR & ROA & & DER & LAR & ROA \\
\hline 2012 & $10,03 \%$ & $0,70 \%$ & $0,01 \%$ & 2015 & $8,09 \%$ & $0,75 \%$ & $0,03 \%$ \\
\hline 2007 & $9,27 \%$ & $0,63 \%$ & $0,02 \%$ & 2014 & $9,49 \%$ & $0,73 \%$ & $0,02 \%$ \\
\hline 2010 & $8,80 \%$ & $0,55 \%$ & $0,02 \%$ & 2013 & $8,60 \%$ & $0,78 \%$ & $0,02 \%$ \\
\hline
\end{tabular}

Sumber : Data yang diolah

Dengan melihat hasil perhitungan dari ketiga rasio diatas menunjukkan bahwa tidak terdapat perbedaan kinerja keuangan pada Bank Mandiri sebelum dan sesudah merger. Hal ini berarti hipotesis kedua yang menyatakan terdapat perbedaan kinerja keuangan pada Bank Mandiri sebelum dan sesudah merger tidak terbukti

Hal ini membuktikan bahwa ternyata keputusan merger yang dilakukan Bank Mandiri belum membawa perubahan yang berarti bagi Bank tersebut. Kinerja keuangan Bank Mandiri tidak mengalami peningkatan yang signifikan,walaupun dari segi profitabilitasnya meningkat. Dalam jangka panjang Bank Mandiri akan lebih memfokuskan strategi bisnisnya pada enam pilar prioritas yaitu bisnis yang bermargin tinggi, diversifikasi dari sumber pendapatan, pertumbuhan dana murah, tranformasi penjualan dan pelayanan, peningkatan efisiensi dan pengembangan sumber daya manusia.

\section{KESIMPULAN DAN SARAN}

Berdasarkan pembahasan yang disampaikan sebelumnya, simpulan yang dapat diambil dalam penelitian ini, adalah penelitian ini membuktikan bahwa terdapat praktik manajemen laba yang dilakukan Bank Mandiri.
Hal ini dibuktikan dengan hasil perhitungan rata-rata total accrual selama lima tahun pengamatan yang bernilai positif. Nilai rata-rata total accrual selama lima tahun pengamatan adalah $0.27,0.24,0.05,0.39$, dan 0.26 . Nilai ratarata total accrual positif menunjukkan terdapat praktik manajemen laba dengan cara menaikkan laba. Penelitian ini membuktikan bahwa tidak ada perbedaan kinerja keuangan yang signifikan yang diproksikan dengan debt to equity ratio (DER), loan to asset ratio (LAR) dan return on asset (ROA) pada laporan keuangan Bank Mandiri sebelum dan sesudah merger.

\section{DAFTAR PUSTAKA}

Bank Indonesia, Peraturan Bank Indonesia No 6/10/PBI/2004 Tanggal 12 April 2004, Perihal Sistem Penilaian Tingkat Kesehatan Bank Umum.

Bank Indonesia, Peraturan Bank Indonesia Nomor 13/1/PBI/2011 Tentang Penilaian Tingkat Kesehatan Bank Umum.

Bank Indonesia, Peraturan Bank Indonesia Nomor 14/14/PBI/2012 Tentang Transparasi dan Publikasi Laporan Bank.

Dharmasetya MM.,BKP, Lani dan Vonny Sulaimin, Msi.,CPA, 2009,Merger dan Akuisisi tinjauan dari sudut Akuntansi dan Perpajakan, Jakarta, PT Elex Media Komputindo KOMPAS 


\section{GRAMEDIA.}

Indrayani, Sita. 2009. "Pengaruh Asimetri Informasi, Konsentrasi Kepemilikan

Institusional dan Leverage Terhadap Manajemen Laba (Studi pada

Perusahaan Properti, Real Estate dan Konstruksi yang Terdapat di BEI)".

Indriani, Yohana 2010, Pengaruh Kualitas Auditor, Corporate Governance, Leverage dan Kinerja Keuangan Terhadap Manajemen Laba (Studi pada Perusahaan Perbankan yang Terdaftar di Bursa Efek Indonesia (BEI) Tahun 20062008), Skripsi, Universitas Diponegoro.

Kartikasari, Novita Senja 2011, Pengaruh Kinerja Keuangan Terhadap Manajemen Laba Pada Perusahaan Perbankan Go Public TAHUN 2007-2011, Skripsi, Universitas Negeri Surabaya,

Sulistiawan, Dedhy, Yeni Januarsi dan Liza Alvia, 2011, Creative Accounting: Mengungkap Manajemen Laba dan Skandal Akuntansi, Jakarta, Salemba Empat.

Sulistyanto, H Sri. 2008. Manajemen Laba: Teori dan Model Empiris. Jakarta: PT Gramedia Widiasarana Indonesia

Teguh, Muhammad. 2009, Metodologi Penelitian Ekonomi, Jakarta, PT Raja Grafindo Persada 